\section{Plant patent quagmire}

SIR - A small inaccuracy in your story on plant patenting (Nature 381, 178; 1996) makes you too pessimistic about prospects for resolving the problem without amending the European Patent Convention.

The Plant Genetics Systems (PGS) decision of the Technical Board (T356/93) caused concern not merely because it was not the result industry needed, but also because of conflict with earlier decisions. PGS was thought to say that claims that 'embraced' plant - or animal — varieties were invalid. But any claim to a plant or animal will normally 'embrace' a variety of that plant or animal. A quite different test was stated in 'Oncomouse' (T19/93): "Is the subject-matter of the application a variety?" In response to this, the resident of the European Patent Office put a question to the Enlarged Board, which has jurisdiction to resolve such conflicts.

But the Enlarged Board refused the question. In a subtle judgement (G3/95), it explained the basis of the Technical Board's decision. Two points had been argued against the claims (it said):

(1) The attacked claims were bad because they 'embraced' plant varieties.

(2) "Claim 21 defines plants (whether or not they are 'plant varieties' in the sense of the UPOV Convention before they are genetically transformed) which have been genetically modified so that they are herbicide-resistant. This characteristic of genetic herbicide resistance is distinctive and stable in succeeding generations of the plants. Thus the claimed genetic modification itself makes the plants 'plant varieties' in the sense of the revised UPOV Convention, 1991...." (Emphasis added.) (UPOV is the Union pour le Protection des Obtentions Végétales, the Union for the Protection of Plant Varieties.)

Although the decision was thought to be based on ground (1), in fact (said the Enlarged Board) it was based only on ground (2). Ground (2) is a new point: so there is no conflict with earlier decisions and the Enlarged Board has no standing to comment.

You are wrong, therefore, in saying that the Enlarged Board confirmed the PGS decision. Nor is this a mere quibble - for in fact the decision in G3/95 completely undermines PGS. Ground (2) - on which the Enlarged Board was careful to make no comment - is clearly untenable. The idea that introducing a single stable gene into any plant material whatever must necessarily produce a UPOV plant variety could only be entertained by someone quite unfamiliar with UPOV practice. UPOV varieties cannot be defined by a single gene: essentially they are defined by all their genes (or at least by all genes that express readily observable characters). If this is pointed out to a Technical Board in some suitable new test case, there should be little further difficulty in obtaining claims to genetically modified plants.

Such a result would make sense. Recent decisions of the European Patent Office on this point fail to consider why plant varieties are excluded from patent protection under the European Patent Convention. This surely was because there was in place a system for protecting plant varieties (UPOV) that was considered more appropriate: and it was felt necessary to shelter this system from competition. If so, there is no reason to deny protection to generic inventions: these cannot possibly be protected under UPOV.

A claim to a plant variety is a claim to a specific subspecies, whereas a claim to a plant containing a transgene is generic. Generic protection is what biotechnologists require - and this requires patents, rather than plant variety rights, useful though the latter are to protect the products of conventional breeding. Biotechnologists who could only obtain protection for particular plant varieties would be in much the same position as authors who could only prevent copying of their books when set in the original typeface.

\section{Tim Roberts}

(Chairman, Biotechnology Committee)

Chartered Institute of Patent Agents,

Staple Inn Buildings,

High Holborn,

London WC1V 7PZ, UK

Address for correspondence: 13 Spring Meadow, Bracknell, Berks RG12 2JP, UK; Email: 70374.26@compuserve.com

\section{Chernobyl legacy}

SIR - I (and others) detect a faint bias in your leading article "Chernobyl's legacy to science" (Nature 380, 653; 1996). You suggest that the true picture is less clear than in fact it is and that the probability is that the consequences will get worse.

Responsible experts and authorities accept that the total number of deaths resulting from the nuclear accident at Chernobyl over the past ten years is 48; three people died immediately after the accident, 28 within days or weeks, 14 in subsequent years (although those included at least two cardiac failures and one car crash) and, more recently, three children have died from thyroid cancer.

There was general agreement about these figures at a meeting of the European Commission and the Ministries of the Republics of Belarus, Russia and Ukraine in Minsk in March, and at a United Nations anniversary conference in Vienna in April.
You quote Ukrainian "health officials" as saying there have been 125,000 deaths, yet neither the prime minister of Ukraine, the Minister for Chernobyl Affairs, Volodymyr Kholosha, nor any of the other Ukrainian scientists and doctors attending the two meetings, dissented from the figure of 48 deaths. Indeed, Kholosha observed that the widely reported figure of 125,000 deaths in the contaminated areas since 1986 was in fact from all causes, and statistically to be expected.

Two of the three republics, Belarus and Ukraine, are known to be using exaggerated figures in the hope of attracting overseas funding to help to resolve their economic problems. The result is to distort public perception of nuclear power generation.

\section{Eric Voice}

25 Miller Place,

Thurso,

Caithness KW14 7UH, UK

\section{Water can be fattening}

SIR - Daedalus's recent scheme (Nature 381, 118; 1996) for refolding pathogenic proteins in vivo rests on the notion that heavy water is only toxic by incongruity with the ordinary kind. Not so: because deuterium weighs twice as much as hydrogen, a bond between deuterium and a heavy atom vibrates with $1 / \sqrt{ } 2$ the frequency of a proton-heavy atom bond. Having lower energy to start with, it takes more energy to break. Administered slowly or instantly, heavy water would act not as a "penetrating oil" on Daedalus's "heavy man", but as sand in his gears.

Deuterium's subtle toxicity might instead make for a suspenseful entertainment. Imagine an important figure, perhaps a head of state, lying in hospital under tight security. An assassin might replace the victim's intravenous feeding solution with one identical but made with heavy water. As the victim became increasingly deuterated he would sink into a deathly torpor. The crime would be averted at the last moment only by the sharp eye of the attending physician, wondering why the patient should have gained 5 or $10 \mathrm{~kg}$ on a liquid diet.

David Schweisguth

Department of Molecular

Biology and Biophysics,

Yale University,

PO Box 208114,

New Haven, Connecticut 06520-8114, USA dcs@proton.chem.yale.edu

Morgagni and the impact factor IN the letter from M. R. Bonati and A. G. Drusini (Nature 381, 271; 1996), G. B. Morgagni's year of birth was incorrect: it should have been 1682 . 